\title{
エッジトーン現象のアクティブ制御と制御機構に関する基礎研究*
}

\author{
藤沢延 行*1, 河 野隆志*2, 高野＼cjkstart剛*1
}

\section{Basic Study on Active Control of Edge Tone and Control Mechanism}

\author{
Nobuyuki FUJISAWA*3, Takashi KOUNO and Tsuyoshi TAKANO \\ *3 Niigata University, Dept. Mechanical and Production Engineering, \\ 8050 Ikarashi-2, Niigata-shi, Niigata, 950-2181 Japan
}

\begin{abstract}
The performance of active feedback control of edge tone phenomenon by the control flow is investigated experimentally and the mehanism is discussed. It is found that the pressure fluctuations over the edge surface are reduced by this control roughly to those of the free jet. The optimum conditions for the phase lag and amplitude of the control flow are obtained quantitatively for various edge distances from the jet nozzle. These results show that the present control technique is very effective for weakening the flow oscillation of the jet-edge system. The flow visualization study suggests that the control mechanism is due to the cancellation of pressure fluctuations created at the edge by the imposed velocity fluctuations.
\end{abstract}

Key Words : Flow Control, Active Control, Unsteady Flow, Edge Tone, Flow Visualization

\section{1. 緒 言}

囋流がくさび状物体に衝突すると、噴流軸に垂直方 向に規則的な自励振動を発生し、いわゆるエッジトー ン現象が発生する。この現象は、流体関連振動や臨音 の発生原因であることから工学上重要であり、流体騒 音の発生機構(1)-(10)や㐨音レベルの低減(11)-(14)などにつ いての研究が活発に行われてきた。過去の研究報告(1) によると、エッジトーン現象の発生機構は、噴流がく さびに衝突する際に発生する圧力変動が上流側に伝播 し噴流出口付近のせん断層を励起し、それが再びくさ び部の生力変動を強めるフィードバックループを形成 するためと考えられている。したがって、その騒音低 減においては、フィードバックループの形成を断ち切 るような手段が有效であり、これまでにも種々のパッ シブな制御法(11)-(14)が提案されている。しかしながら、 円柱後流(15)-(18)、はく離せん断層 ${ }^{(19)}$ など種々の流れ場に 刘してアクティブ制御の適用がしばしば検討され始め ており、今後の適用鉴囲の拡大と制御性能の改善が期 街されている。Ziada(19)は、エッジトーン現象に対して

\footnotetext{
* 原稿受付 1999 年 11 月 19 日.

*1 正員, 新潟大学工学部(西950-2181 新潟市五十嵐 20 町 8050).

*2 学生員, 新鼬大学大学院

E-mail : fujisawa@eng.niigata-u.ac.jp
}

アクティブ制御法を初めて適用し、その有効性を示唆 した。しかしながら、制御パラメータについての定量 化や制御機構についての検討など多くの流体力学的課 題については不明のままであり、更なる今後の検討が 待たれている。

本研究では、エッジトーン現象に対するフィード バック制御の有効性と制御機構を明らかにするため、 それを支配する制御パラメータの影響とその制御機構 をくさび表面の圧力変動測定と流れの可視化による観 察から検討することを目的とする。

\section{2. 実験装置および方法}

2 - 1 実験装置 図 1 に実験装置の概略を示す。供 試風洞吹出し口下流側（断面寸法 $200 \mathrm{~mm} \times 200 \mathrm{~mm} ） に$ ノズル出口愊 $\mathrm{d}=20 \mathrm{~mm}$ の二次元ノズル（奥行き $200 \mathrm{~mm}$ ) を水平に固定し、さらにその下流側に頂角 $28^{\circ}$ の二等 辺三角形のくさびを設置して、噴流くさび系の実駼装 置とした。ただし、くさび状物体の流れに垂直方向の

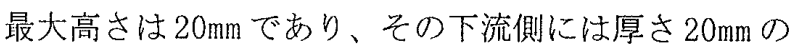
平板を固定した。くさびの先端はノズル中心と一致す るように置かれており、くさびの付いた平板は両側の 端板の瑇に沿って移動させることで、くさび状物体と ノズル閒の距㰚 $\mathrm{x}$ を任意に変化できるようにした。ま

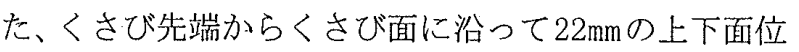


犆には直径 $1 \mathrm{~mm}$ の圧力孔が設けられており、そこでの 压力をステンレス製導管を通してひずみゲージ式圧力 変换器で钼测できるようにした。ただし、本実験で使 用した圧力変撸器は、 $200 \mathrm{~Hz}$ まで平坦な周波数特性を 有している。一方、噴流吹出し口付近の上下には制御 朋スピーカが 2 個取り付けられており、噴流の上下か ら発振現鱼を制御するための変動流を制御ノズルを通 して供給できるように設計した。ただし、制御変動流 の吹出し口高さは $3 \mathrm{~mm}$ である。なお、以上の供試ノズ ル、くさび、制御ノズルは、いずれもスパン方向に $200 \mathrm{~mm}$ の愊を有している。

$2 \cdot 2$ 制御システム 本実験のフィードバック制御 は、くさび上面で検出した圧力変動を AD変换しコン ピュータで位相ならびにグインを変化させた後D A変 換し、さらに電力增愊した信号を2個のスピーカの入 力信号として使用する。したがって、制御信号の位相 とグインはコンピュータで任意に変化させることにな る。一才、予備実験において、くさび表面圧力変動と 制御ノズルからの速度変動の同時測定を行い、両信号 閆の位相を調べたところ、本実験の周波数範囲におい て 5-10ms 程度の遅れが認められた。この主因は、制御 ノズルにおける信号の遅れによるものであるが、本実 験では、周波数ごとにこの遅れを計測し、この関係に 基いて位相遅れを補正した。ただし、制御ノズル出口 部の速度变動は、熱線流速計を用いて測定した。その 速度検定には、低速であるため、あらかじめ中空卜 レーサ粒子を用いたP I V法による速度とブロア回転 数の関係を测定しておき、制御ノズル出口部の速度を 测定した。ここに、制御ノズル出口における速度変動

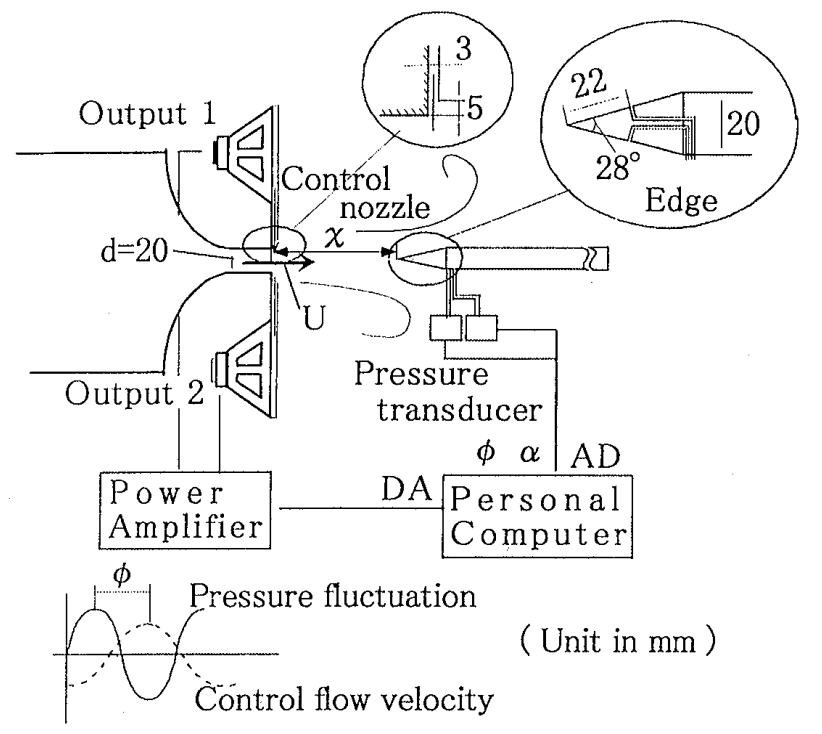

Fig. 1 Experimental apparatus and control system
は、振動流であるため、その速度振幅 vによって制御 流の大きさを表すことにした。以下では、それをノズ ル出口速度Uで無次元化して制御流振幅 $\alpha(=\mathrm{v} / \mathrm{U})$ で示 す。実騟は、ノズル出口流速 $\mathrm{U}=10 \mathrm{~m} / \mathrm{s} 、 15 \mathrm{~m} / \mathrm{s} 、 20 \mathrm{~m} / \mathrm{s}$ で行ったが、それらはノズル出口幅的に基くレイノル ズ数 $(=\mathrm{Ud} /$ v $)$ に換算するとそれぞれ13200、19800、 26500 である( $(\nu:$ 流体の動粘度)。

$2 \cdot 3$ 流れの可視化 流れの可視化は、スモーク供 給装置で作ったスモークを供試吹出し型風洞のブロア 吸込多口から直接供給して行った。光源としては、ア ルゴンイオンレーザ4Wをシート状にして装置上側から 照射し、二次元噴流の中央断面付近における流れ場を 可視化した。ただし、供試くさび，下流側平板ならび にこれらを固定する端板はアクリル製であり、一方の 端板を通してくさび付近の全流孔場を観測できるよう にした。なお、その観測には、モノクロCCDカメラ $(768 \times 494$ ピクセル) を用いた。ただし、可視化観測 と同時にくさび面の圧力変動の時間変化も同時計測す ることで、種々の圧力位相における流れ場の条件付き 可視化観測 (20)を行った。

\section{3. 結果および考察}

$3 \cdot 1$ 無制御時の流動特性 図 2 は、くさび面で検 出された圧力変動係数 $\mathrm{Cp}^{\prime}\left(=2 \sqrt{\overline{\overline{\mathrm{p}^{\prime 2}}}} / \rho U^{2}\right)$ がノズル

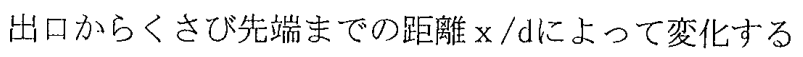

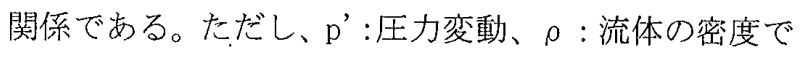
ある。圧力変動係数 Cp'の分布は、わずかにレイノル ズ数の影響を受けるが、いずれの流速Uの結果におい てもノズルからの距離 $\mathrm{x} / \mathrm{d}=5$ 付近で最大となる分布形 状を示す。このような圧力変動と距離 $\mathrm{x} / \mathrm{d}$ の関係は、く さび形状、圧力測定位置ならびにレイノルズ数の影響 を受けるため、過去の結果(9) との定量的比較は困難で あるが、分布形状ならびに分布が最大となる位置につ

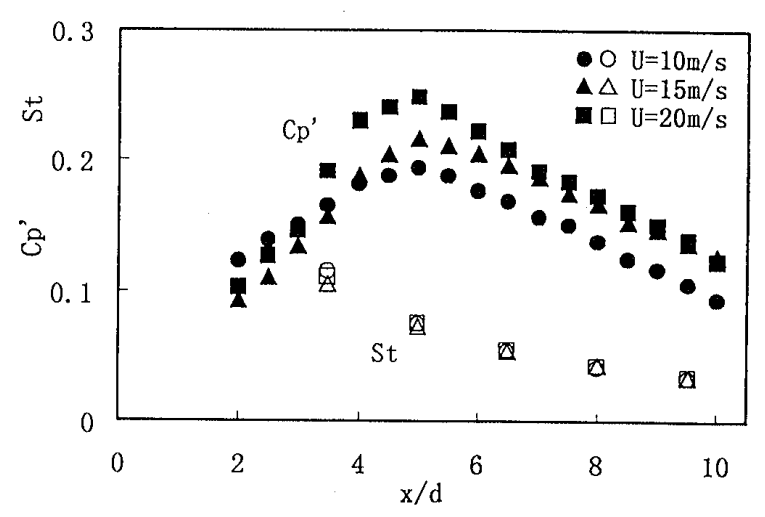

Fig. 2 Distributions of fluctuating pressure coefficient $\mathrm{Cp}^{\prime}$ and Strouhal number $\mathrm{St}$ 


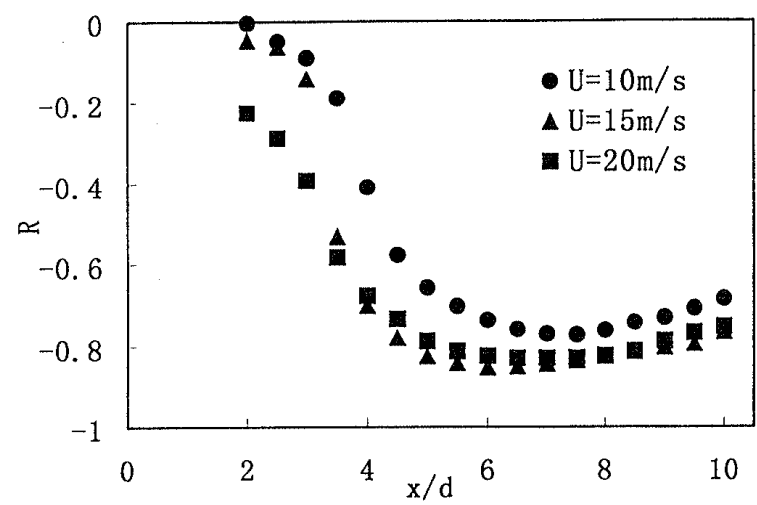

Fig. 3 Distributions of correlation coefficient $R$ of fluctuating pressure

いての定性的一致は得られている。したがって、 $\mathrm{x} / \mathrm{d}=5$ 付近におけるCp' の増加は、過去の実験(1)-(10) と同様に、 エッジトーン現象の発生によるものと考えられる。図 2 には、压力変動の支配周波数 $\mathrm{f}$ からストロハル数 St (=fd/U)を算出した結果も示した。ストロハル数Stは、 距雉 $\mathrm{x} / \mathrm{d}$ の增大と共に徐々に減少する傾向を示すが、 その関係は圧力変動分布に見られたようなレイノルズ 数の影響恃認められない。なお、本実験の Cp'，St の不 確かさは、約 $95 \%$ 包括度で、それぞれ $5.2 \%$ と.0 \%である。

図 3 は、くさび上下の圧力変動の相互相関係数 $\mathrm{R}$ $\left(\overline{=\mathrm{p}_{1}^{\prime} \mathrm{p}_{2}} / \sqrt{\overline{\mathrm{p}_{1}^{2}}} \sqrt{\overline{\mathrm{p}_{2}^{2}}}\right)$ と距離 $\mathrm{x} / \mathrm{d}$ の関係である。こ こに、添字 1,2 はそれぞれくさびの上下を表す。いず れの流速Uに掠いても $\mathrm{x} / \mathrm{d}$ が 4 付近より大きくなると 相互相関係数は負の大きな值を示し、エッジ上下面に おいて互いに反対の圧力変動を示す発振現象が生じて いることがわかる。このことが、図 2 の圧力変動の増 大に寄与していると考えられる。一方、 $\mathrm{x} / \mathrm{d} か ゙ 4$ 以下の 領域ではエッジ上下面間の圧力変動の相関は小さく、 規則的な発振現象は弱まることになる。なお、本実験 のRの不確かさは、約 $95 \%$ 包括度で、11.6\%である。

3.2 アクティブ制御時の流動特性 図 4 は、本 実牄の顀流くさび系に対しフィードバック制御を適用 した際の圧力変動係数 Cp' の変化を示す。ただし、実 賖結果はノズル出口流速 U=15m/s の場合である。制御 信号としてはくさび上面の圧力変動信号を用い、それ に対し位相遲れとフィードバックゲインをコンピュー タで設定してスピーカから変動制御流を与えた。ここ では、制御信号の出力位置がノズル上部、ノズル下部、 そしてノズル雨側の 3 種の場合について検討した。こ のうち、くさびの両側からの2出力の場合には、予備 実験の結果から、上下のスピーカに対する制御信号入 力は逆位相時に最適な制御效果が得られたことから、

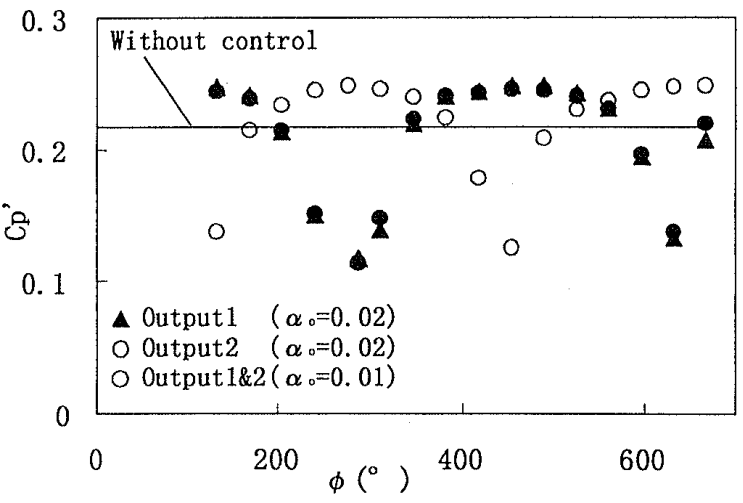

Fig. 4 Effect of phase $\operatorname{lag} \phi$ at optimum oscillation amplitude $(\mathrm{x} / \mathrm{d}=5, \mathrm{~J}=15 \mathrm{~m} / \mathrm{s})$

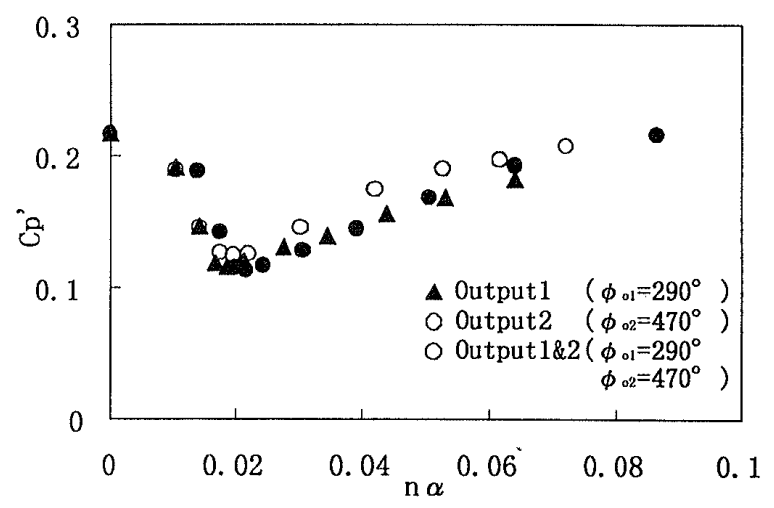

Fig. 5 Effect of oscillation amplitude $\alpha$ at optimum phase $\operatorname{lag}(x / d=5, U=15 \mathrm{~m} / \mathrm{s})$

それに固定した。なお、これらの結果はいずれも圧力 変動係数 $\mathrm{Cp}^{\prime}$ が最も小さくなるように最適な制御流振 愊 $\alpha$ 。を選択したときの結果である。図 4 によると、い ずれの制御出力においても、圧力変動係数は位相遅れ の影響を強く受け、ある位相遅れにおいて圧力変動係 数は最小值を示すことが分かる。しかしながら、出力 1 と出力 2 の結果からわかるように、制御信号の出力 スピーカを上下反対にすると、両者の最適位相遅れは 約 $180^{\circ}$ 変化する。これは、図 3 に示したように、く さび部に形成される流れ場がその上下で逆位相の関係 にあるためである。一方、制御信号の出力スピーカが ノズル上側の場合と両側の場合の結果 ( $\phi=\phi$, の場合) は、かなり良く一致しており、いずれも位相遅れ $\phi$ $=290^{\circ}$ 付近で $\mathrm{Cp}$ ' は最小になる。このことは、一方の せん断層に対し制御を加えるだけで十分な制御効果が 得られることを示すとともに、このCp' の最小值は無 制御時よりも小さく、制御による圧力变動の抑制効果 を示す。また、 1 出力の制御流振幅は $\alpha$ 。 $=0.02$ である のに対して、2出力の場合には $\alpha_{0}=0.01$ となり、制御 流振愊が半分となっていることは注目すべきである。 


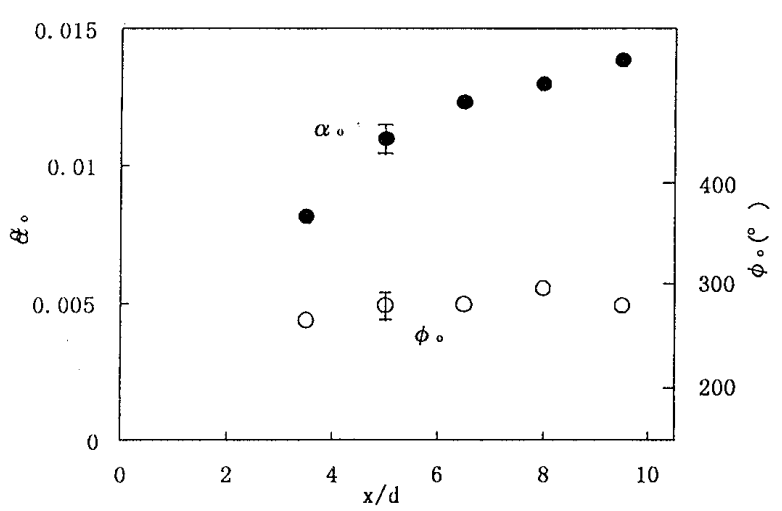

Fig. 6 Distributions of optimum control parameters $\alpha_{0}$ and $\phi_{0}$

このことは、いずれの場合にも供給する制御エネル ギーは等価であることを示唆する。一方、最適位相遅 れ $\phi_{0}=290^{\circ}$ に対し逆位相となる $\phi=470^{\circ}$ 付近では圧 力変動は最大となり、またその值は無制御時より大き く、発振現象が強められたことを示す。

図 5 は、位相遅れを最適值 $\phi$ 。に固定し、スピーカ に供給する制御流振幅を種々変えた場合の圧力変動倸 数分布である。ただし、図 5 の横軸は出力数 $\mathrm{n}$ と制御 流振幅 $\alpha$ の積で表した。いずれの結果においても、n $\alpha$ $=0.02$ 付近に㧍いて圧力変動係数 $\mathrm{Cp}^{\prime}$ 吕最小值を示す こと、ならびにいずれもほぼ一致した分布形状となる。 枆制御時 $(\alpha=0)$ の压力変動係数 $\mathrm{Cp}^{\prime}(=0.22)$ と比較 すると、位相遅れと制御流振幅を最適にした最適制御 時の Cp'は、0.12 程度まで減少しており、圧力変動は 約半分程度に減少したことになる。このように、最適 制御時では淛御出力の位置や数による制御效果の違い は少なく、以下では上下逆位相 2 出力での実験結果に ついて詳しく考察する。

図 6 は、本制御実験においてノズルからくさび先端 までの距離 $\mathrm{x} / \mathrm{d}$ を種々変えたときの最適位相遅れ $\phi$ 。 と最逼制御流振愊 $\alpha$ 。の变化関係を示す。ただし、 $\mathrm{U}=15 \mathrm{~m} / \mathrm{s}$ の結果である。ノズルからの距雖 $\mathrm{x} / \mathrm{d}$ が増大 しても、最適位相 $\phi$ 。はほぼ一定の值 $\phi 。=290^{\circ}$ を示 す。これは、くさびによって誘起された圧力変動がノ ズルから発達するせん断尿に伝播し制御に至る時間が 一分短いため、最適位相遅れがくさび位置の影響を受 けないと考えられる。一方、最適制御流振愊 $\alpha$ 。は距 雕 $\mathrm{x} / \mathrm{d}$ とともに增大寸る傾向にある。これは、くさび

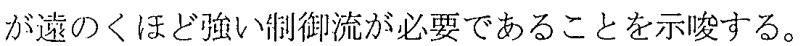

図 7 は、本実踰のエッジトーン現象に対してアク ティブ制御を楜用した際のくさび面上の圧力変動なら びにストロ八ル数がくさび位淔 $\mathrm{x} / \mathrm{d}$ によって変化する 閵係を示す。本アクティブ制御によるくさび表面の圧

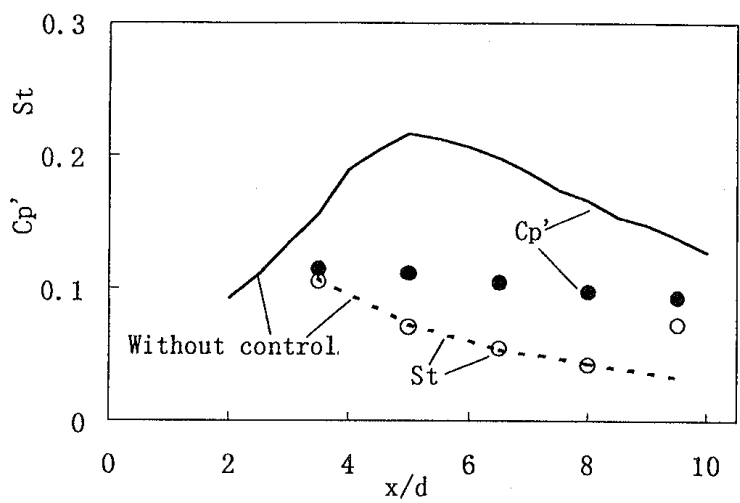

Fig. 7 Distributions of fluctuating pressure coefficient $\mathrm{Cp}^{\prime}$ and Strouhal number St under optimum control

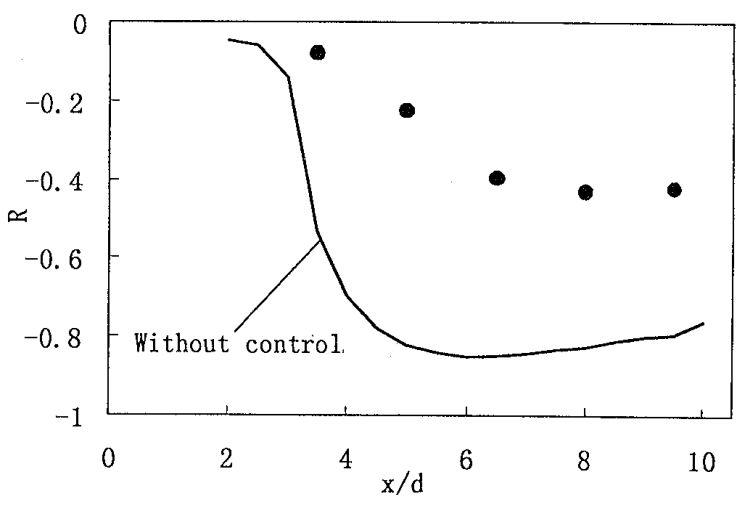

Fig. 8 Distributions of correlation coefficient $R$ of fluctuating pressure under optimum control

力変動の抑制効果は、いずれの $\mathrm{x} / \mathrm{d}$ の位置においても 認められる。しかしながら、その抑制効果の大きさは 位置の関数であり、最も大きな抑制効果は $\mathrm{Cp}^{\prime}$ が最大 値を示す $\mathrm{x} / \mathrm{d}=5$ 付近で得られている。なお、最適制御 時のCp'の分布はx/dが増すとわずかに減少するが、ほ ぼ一定の分布形状である。このことは、制御効果に よって噴流くさび系に発生する特定周波数における発 振現像が抑制されたことを示す。一方、ピト一管の静 圧孔を利用して、本実歌でのくさびを取り外した状態 の二次元自由噴流における静圧変動を測定したところ $\mathrm{x} / \mathrm{d}=3.5-9.5$ の範国でCp' $=0.08$ であった。この結果は、 本実騟の噴流くさび系における制御時の圧力変動值 $\mathrm{Cp}^{\prime}=0.12$ よりわずかに小さい值であり、本制御結果は 自由噴流の場合に漸近すると考えられる。このことは、 本制御が特定の周波数成分に対してのみ有効であるた め、それ以外の周波数成分に対する影響は小さいこと を示唆与る。一方、図 7 によると、ストロハル数の分 布は然制御洔とほぼ一致しており、本制御が噴流くさ び系の発振周波数に対する影響は小さい。

図 8 は、くさび上下面閒の圧力変動の相互相関係数 


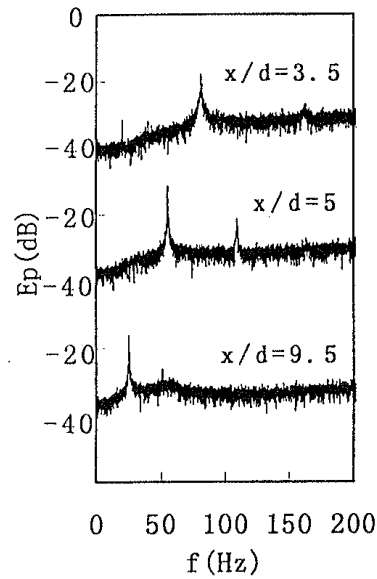

(a) Without control

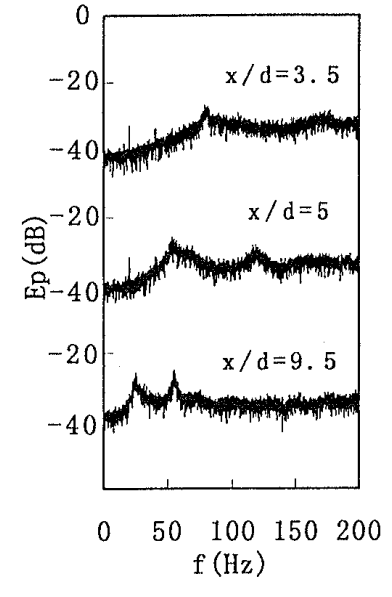

(b) Optimum control
Fig. 9 Amplitude spectrum of fluctuating pressure over edge surface

$R の$ 值がくさび先端位置 $\mathrm{x} / \mathrm{d}$ によって変化する関係を 制御時ならびに無制御時について示した結果である。 制御特の相関係数は、くさび位置が増加寸ると徐々に 減少しており、無制御時と同様な分布形状を示す。し かしながら、定量的には、無制御時の $\mathrm{x} / \mathrm{d}>4$ で見られ た強い負の相関 $R=-0.8$ は制御時には $R=-0.4$ 程度の值 を示し、圧力変動の相関は制御により抑制される。こ のことは、本制御はくさび上下面に形成される規則的 流れパターンの抑制に対し有效であり、その結果規則 的パターンは弱まることになる。一方、 $\mathrm{x} / \mathrm{d}<3.5$ では 㫼御の有無に関わらず負の相関係数は小さく、ランダ ムな流れパターンを示すことが予期される。したがっ て、このような場合には本制御は有効とは言えず、図 7 に示したように本制御による圧力変動の抑制効果は 小さい。

図 9 は、種々のくさび位置 $\mathrm{x} / \mathrm{d}$ におけるエッジ上面 の圧力変動の周波数分析結果であり、それを器制御時 (a) と最適制御時 (b)について比校して示した。ただし、 図の縦軸怯、 $\mathrm{Cp}^{\prime}=\int_{0}^{\infty}$ Epdf で定義される振幅スペク トル関数 $\mathrm{Ep}$ であり、横軸 $\mathrm{f}$ は周波数 $(\mathrm{Hz})$ である。無制 御㭙における結果によると、かなり明嘹な特定の周波 数における圧力変動のピークがいずれのくさび位置の 結果においても認められており、噴流くさび系におけ る発振現象の発生を示す。ただし、いずれのくさび位 琶においても基本調波に刘応する1次ピークならびに その 2 倍の周波数における 2 次ピークが認められる。 くさび位置 $\mathrm{x} / \mathrm{d}=5$ の結果によると、 1 次と 2 次の圧力 変動成分のピークは共に、他のくさび位置より大きく、 図 2 の圧力变動の测定結果と対応する。一方、制御時 に战ける周波数分析結果によると、いずれのくさび位 犆においても、圧力变動のピーク值はかなり小さくな

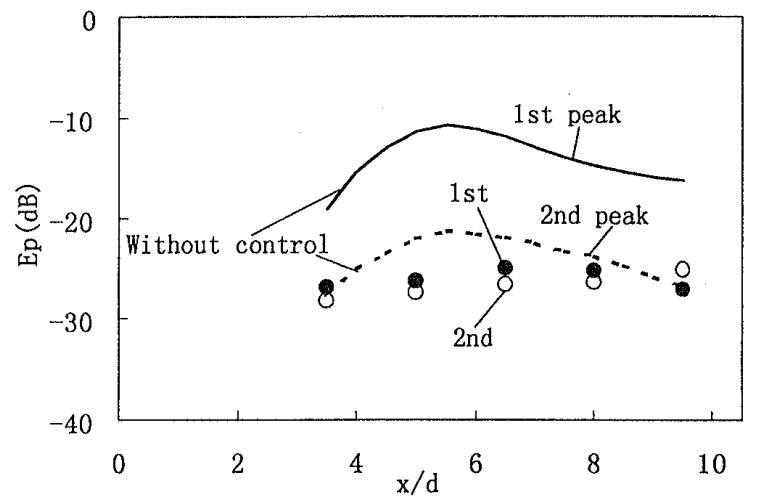

Fig. 10 Peak anplitude spectrum of fluctuating pressure under optimum control

り、より平坦な分布形状を示す。ここに、圧力変動の ピークの減少に対応して、ピーク周波数付近では圧力 変動成分に多少の增大傾向が見られており、その結果 として分布形状が平滑化されることがわかる。一方、 くさび位置 $\mathrm{x} / \mathrm{d}=9.5$ の結果によると、制御によって 2 次ピークがかなり增大しており、その大きさは1次 ピークより大きくなる。これは、制御によって発振 モードが遷移(10)したことを示す。

図 10 は、このような周波数分析結果から 1 次なら びに 2 次の圧力変動のピーク值を読み取り、くさび位 犆 $\mathrm{x} / \mathrm{d}$ との関係を示した結果である。無制御時におい ては、1次と 2 次ピークいずれも $\mathrm{x} / \mathrm{d}=5$ 付近に最大を 持つ分布形状であり、図 2 に示した $\mathrm{Cp}^{\prime}$ の測定結果と 同様である。一方、制御時には 1 次 2 次いずれのピー クもくさび位置に依らずより平坦な分布形状を示す。 ここに、制御による圧力変動の滅衰効果は $\mathrm{x} / \mathrm{d}=5$ の位 置の 1 次ピークに強く認められ、その減衰量は $15 \mathrm{~dB}$ 程 度である。2 次ピークにも同様の減衰効果が認められ るが、その減衰量惊さい。このとき、くさび位置が 下流方向へ移動すると、2 次ピークは徐々に增大し、 $\mathrm{x} / \mathrm{d}=9.5$ では先にも述べたように 2 次ピークが 1 次 ピークより大きくなる。

図 11 は、くさび上面の圧力変動の計測と同時にく さび周りの流れ場を可視化観测した結果であり、哭制 御時と最適制御洔の結果を対比して示す。ただし、く さび上面の圧力変動の時間変化の最大 (a) および最小 （b）における流れ場の可視化結果を示した(図1の圧力 波形参照)。無制御時における結果を見ると、圧力が最 大時にはくさび上面側のスモークは減少し、くさび面 に沿う增速流の発生が予期される。それに対し、くさ び下面側ではスモークが増大し、減速流の発生を示唆 する。一方、圧力の最小時には、最大時とは反対にく さび上面には滅速流、下面には增速流が観測される。 


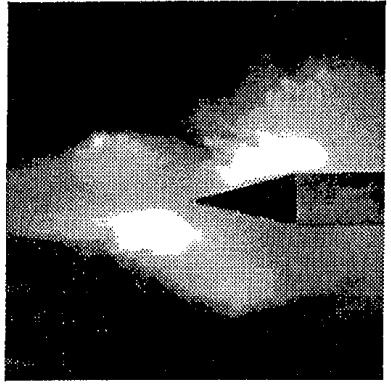

Without control

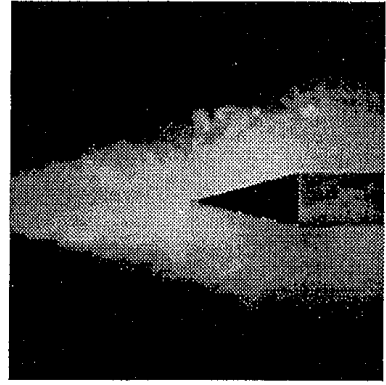

Optimum control

(a) Maximum pressure phase

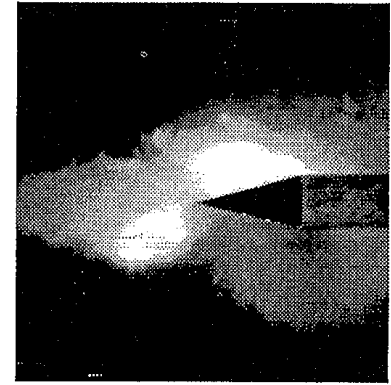

Without control

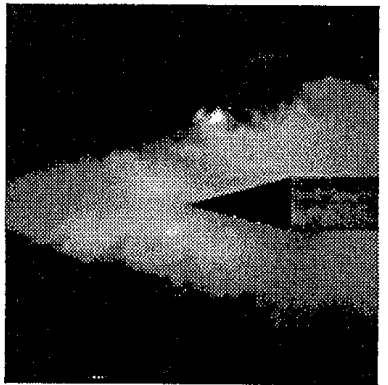

Optimum control

(b) Minimun pressure phase

Fig. 11 Flow visualizations with respect to pressure phase

このように、無制御時ではくさび表面の圧力変動と流 れ場の閒には強い相関が観測され、図 3 に示したよう に、くさび上下面間には強い負の相関が発生したこと に対応する。一方、最適制御結果を見ると、このよう なくさび周りに発生する流れ場の発振現象は、かなり 強く抑制され、压力変動の位相に関わらず流れはくさ び軸に対し対称に下流方向に発達する。このことは、 本制御によって、噴流くさび系に形成される流体の発 振現象が抑制されたことを示しており、この制御法の 有效性老示唆与る。

\section{4. 結言}

噴流・くさび系における発振現象の制御とそのメ力 ニズム解明を目的とし、くさび面の圧力変動をフィー ドバックし、ノズル部付近に取り付けたスピーカから 微小挸乱を与えるアクティブ制御法を実験的に検討し、 以下の結諭を得た。

(1) 本アクティブ制御によって噴流くさび系に発生する 発振現象を制御するためには、最適な位相遅れと制御 流振愊の組み合わせが重要であり、これらの最適值を 定量的に示した。本実験の範囲では、最適位相遅れは $290^{\circ}$ 付近で、それはくさび位置に依らず、制御流振幅 は0.02程度であるが、それはくさび位置によって変化 する。

(2) 本アクティブ制御は、くさび表面の圧力変動の発振 周波数成分を抑制するのに有効であり、制御下におけ る压力変動仗くさび位置に依らずほぼ一定の值を示す。
また、この圧力変動值は、自由噴流の場合に漸近する。 （3）くさび表面の圧力変動の测定と同時にスモークに よる流れ場の可視化観察を行い、圧力パターンによる 流れパターンの変動の観察と本制御による発振現象の 抑制効果を示した。

\section{文献}

(1) Rockwell, D. and Naudascher, E, Ann. Rev. Fluid Mech., 11(1979), 67-94.

（2）林頻・他 3 名, 計測制御論, 16-6 (1989), 892-897.

(3) Lucas, M. and Rockwe11. D. , J. Fluid Mech., 147 (1984), 333-352.

（4）望月修・ほか 2 名, 機論 51-467 (1985), 2258-2264.

（5）社河内敏彦・ほか3名，機論51-469(1985)，2897-2907.

(6) Kaykayoglu, R. and Rockwell D., J. Fluid Mech. 169 (1986), 125-149; 151-172.

(7) Krorhapalli, A. and Horne, W. C., AIAA J., 24-8(1986), 1385-1388.

（8）社河内敏彦・ほか2名，機論 52-480(1986)，2872-2880.

（9）佐野学, 水牧祥一, 機論 54-500(1988)，791-797.

(10) Haga, A. and Hosoi, Y., Third Asian Symposium on Visualization, Chiba, 1994, 149-154.

（11）白浜芳郎・ほか 2 名，機論 57-542(1991)，3402-3407.

（12）池田敏彦・ほ加3名，可視化情報，15-58（1995)，183-189。

（13）池田敏彦・ほか 4 名, 機論 62-597(1996), 1841-1846.

（14）池田敏彦・住汃 4 名，航宇誌，45-522 (1997)，404-410。

(15) Ffowcs Williams, J.E. and Zhao, B.C., J. Fluids Struct., 3(1989), 115-122.

（16）藤沢延行, ワルイ , H. M. , 機諭 61-585 (1995) , 1827-1831.

（17）藤沢延行, 川路泰司, 機諭61-585 (1995), 1832-1836.

(18) Warui, H.M. and Fujisawa, N., Exp. Fluids, 21 (1996), 49-56.

(19) Ziada, S, J. Fluids Struct., 9(1995), 907-923.

（20）藤沢延行 ·他 2 名，機論 62-593 (1996), 109-114. 